This copy is for your personal, non-commercial use only.

If you wish to distribute this article to others, you can order high-quality copies for your colleagues, clients, or customers by clicking here.

Permission to republish or repurpose articles or portions of articles can be obtained by following the guidelines here.

The following resources related to this article are available online at www.sciencemag.org (this information is current as of February 22, 2010 ):

Updated information and services, including high-resolution figures, can be found in the online version of this article at:

http://www.sciencemag.org/cgi/content/full/327/5968/990

Supporting Online Material can be found at:

http://www.sciencemag.org/cgi/content/full/327/5968/990/DC1

A list of selected additional articles on the Science Web sites related to this article can be found at:

http://www.sciencemag.org/cgi/content/full/327/5968/990\#related-content

This article cites 13 articles, 2 of which can be accessed for free:

http://www.sciencemag.org/cgi/content/full/327/5968/990\#otherarticles

This article has been cited by 1 articles hosted by HighWire Press; see:

http://www.sciencemag.org/cgi/content/full/327/5968/990\#otherarticles

This article appears in the following subject collections:

Paleontology

http://www.sciencemag.org/cgi/collection/paleo

Science (print ISSN 0036-8075; online ISSN 1095-9203) is published weekly, except the last week in December, by the American Association for the Advancement of Science, 1200 New York Avenue NW, Washington, DC 20005. Copyright 2010 by the American Association for the Advancement of Science; all rights reserved. The title Science is a registered trademark of AAAS. 
and the other $\pi$ face shielded by the catalyst, and are all expected to be energetically accessible under the reaction conditions. Computational analyses using either density functional theory or $\mathrm{ab}$ initio methods (Fig. 4, C to E) predict that the enantioselectivity-determining cycloaddition occurs preferentially with complex $\mathbf{I}$, leading to the experimentally observed $(R)$-enantiomer of product $\mathbf{4 a}_{\mathbf{e x o}}$. The lowest-energy cycloaddition transition structure displays iminium $\mathrm{N}-\mathrm{H} \cdots \mathrm{O}_{\text {sulfinamide }}$ and formyl $\mathrm{C}-\mathrm{H} \cdots \mathrm{O}_{\text {sulfonate }}$ hydrogen bonds (Fig. 4C), and is predicted to have $\geq 1.3-\mathrm{kcal} / \mathrm{mol}$ lower energy than alternatives arising from complexes II to IV, which is consistent with the experimental data. The basis for enantioselectivity may be ascribed to a stabilizing $\pi-\pi$ interaction between the $\left(\mathrm{CF}_{3}\right)_{2}-\mathrm{C}_{6} \mathrm{H}_{3} \mathrm{~N}$ component of the catalyst and the cationic aniline moiety of the substrate. This interaction is evident in transition structures leading to the major enantiomer of $\mathbf{4} \mathbf{a}_{\mathbf{e x o}}$ (Fig. 4D), but it is absent in transition structures leading to the minor enantiomer (Fig. 4E).

Enantioselective catalysis by $\mathbf{1 a}$ of a strong Brønsted acid-catalyzed Povarov reaction thus involves tight binding to a highly reactive cationic intermediate through multiple, specific H-bonding interactions, and these noncovalent interactions are maintained in the subsequent stereodetermining cycloaddition event. One of the four energetically accessible ground-state complexes undergoes reaction with the nucleophile preferentially, illustrating the ability of bifunctional catalyst 1a to control precisely the outcome of this reaction through noncovalent interactions alone. Given the known ability of urea and thiourea derivatives to bind a wide range of anions, the strategy demonstrated here is applicable, in principle, to cationic intermediates with a variety of counterion structures.

\section{References and Notes}

1. M. Eigen, Angew. Chem. Int. Ed. Engl. 3, 1 (1964).

2. T. Akiyama, ]. Itoh, K. Yokota, K. Fuchibe, Angew. Chem. Int. Ed. 43, 1566 (2004).

3. D. Uraguchi, K. Sorimachi, M. Terada, J. Am. Chem. Soc. 126, 11804 (2004).

4. T. Akiyama, Chem. Rev. 107, 5744 (2007).

5. D. Nakashima, H. Yamamoto, J. Am. Chem. Soc. 128, 9626 (2006).

6. M. Hatano, T. Maki, K. Moriyama, M. Arinobe, K. Ishihara, J. Am. Chem. Soc. 130, 16858 (2008).

7. K. Ishihara, M. Kaneeda, H. Yamamoto, J. Am. Chem. Soc. 116, 11179 (1994).

8. H. Yamamoto, K. Futatsugi, Angew. Chem. Int. Ed. 44, 1924 (2005).

9. T. Weil, M. Kotke, C. M. Kleiner, P. R. Schreiner, Org. Lett. 10, 1513 (2008).

10. R. S. Klausen, E. N. Jacobsen, Org. Lett. 11, 887 (2009).

11. D. Seebach, H. A. Oei, Angew. Chem. Int. Ed. Engl. 14, 634 (1975).

12. I. T. Raheem, P. S. Thiara, E. A. Peterson, E. N. Jacobsen, J. Am. Chem. Soc. 129, 13404 (2007).

13. Z. Zhang, P. R. Schreiner, Chem. Soc. Rev. 38, 1187 (2009).

14. A. G. Doyle, E. N. Jacobsen, Chem. Rev. 107, 5713 (2007).

15. V. V. Kouznetsov, Tetrahedron 65, 2721 (2009).

16. H. Ishitani, S. Kobayashi, Tetrahedron Lett. 37, 7357 (1996).

17. T. Akiyama, H. Morita, K. Fuchibe, J. Am. Chem. Soc. 128, 13070 (2006).

18. H. Liu, G. Dagousset, G. Masson, P. Retailleau, ]. P. Zhu, J. Am. Chem. Soc. 131, 4598 (2009).

19. Materials and methods are available as supporting material on Science Online.

20. K. L. Tan, E. N. Jacobsen, Angew. Chem. Int. Ed. 46, 1315 (2007).

21. P. D. Leeson et al., J. Med. Chem. 35, 1954 (1992).
22. R. A. Batey, P. D. Simoncic, D. Lin, R. P. Smyj, A. J. Lough, Chem. Commun. (Camb.) (7): 651 (1999).

23. M. Takamura, K. Funabashi, M. Kanai, M. Shibasaki, J. Am. Chem. Soc. 123, 6801 (2001).

24. K. M. Witherup et al., J. Am. Chem. Soc. 117, 6682 (1995).

25. C. F. Xia, L. S. Heng, D. W. Ma, Tetrahedron Lett. 43, 9405 (2002).

26. H. Mayr, A. R. Ofial, E. U. Wurthwein, N. C. Aust, J. Am. Chem. Soc. 119, 12727 (1997).

27. M. J. Frisch et al., Gaussian 03, Revision E.01 (Gaussian, Wallingford, CT, 2004).

28. G. R. Elia, R. F. Childs, J. F. Britten, D. S. C. Yang, B. D. Santarsiero, Can. J. Chem. 74, 591 (1996).

29. P. Vachal, E. N. Jacobsen, J. Am. Chem. Soc. 124, 10012 (2002).

30. P. R. Schreiner, A. Wittkopp, Org. Lett. 4, 217 (2002).

31. J. L. Sessler, P. A. Gale, W.-S. Cho, Anion Receptor Chemistry (RSC Publishing, Cambridge, UK, 2006).

32. T. R. Kelly, M. H. Kim, J. Am. Chem. Soc. 116, 7072 (1994).

33. J. González, K. N. Houk, J. Org. Chem. 57, 3031 (1992).

34. N. Isaacs, In: Physical Organic Chemistry. (Wiley, New York, 1995), pp. 296-301.

35. This work was supported by NIH (grants GM-43214 and P50 GM-69721) and by fellowship support from the Dreyfus Foundation (to H.X.), the American Chemical Society and Roche (to S.J.Z.), and the American Chemical Society through the Irving S. Sigal Postdoctoral Fellowship (to M.G.W.). We thank L. P. C. Nielsen for helpful discussions. Metrical parameters for a derivative of compound $4 a_{\text {exo }}$ are available free of charge from the Cambridge Crystallographic Data Centre.

\section{Supporting Online Material}

www.sciencemag.org/cgi/content/full/327/5968/986/DC1

Materials and Methods

SOM Text

Figs. S1 to S19

Tables S1 to S17

References

5 October 2009; accepted 13 January 2010

$10.1126 /$ science. 1182826

\section{0-Million-Year Dynasty of Giant Planktivorous Bony Fishes in the Mesozoic Seas}

\author{
Matt Friedman, ${ }^{1 *}$ Kenshu Shimada, ${ }^{2,3}$ Larry D. Martin, ${ }^{4}$ Michael ]. Everhart, ${ }^{3}$ ]eff Liston, ${ }^{5}$ \\ Anthony Maltese, ${ }^{6}$ Michael Triebold ${ }^{6}$
}

Large-bodied suspension feeders (planktivores), which include the most massive animals to have ever lived, are conspicuously absent from Mesozoic marine environments. The only clear representatives of this trophic guild in the Mesozoic have been an enigmatic and apparently short-lived Jurassic group of extinct pachycormid fishes. Here, we report several new examples of these giant bony fishes from Asia, Europe, and North America. These fossils provide the first detailed anatomical information on this poorly understood clade and extend its range from the lower Middle Jurassic to the end of the Cretaceous, showing that this group persisted for more than 100 million years. Modern large-bodied, planktivorous vertebrates diversified after the extinction of pachycormids at the Cretaceous-Paleogene boundary, which is consistent with an opportunistic refilling of vacated ecospace.

$\mathrm{T}$ he largest vertebrates - fossil or livingare marine suspension feeders. Modern clades adopting this ecological strategy diversified in the Paleogene (66 to 23 million years ago) (1-3) and include baleen whales and four independent lineages of cartilaginous fishes (sharks and rays) (4). In striking contrast to the array of giant suspension feeders found in Cenozoic marine environments, this guild has appeared to be absent during most of the Mesozoic, an interval that is marked by the ecological ascendance of modern plankton groups $(5,6)$. Possible candidates have been proposed $(7,8)$, but the clearest examples of large-bodied planktivores in the Mesozoic seas have been a handful of bony fishes confined to a brief 20-million-year window during the Jurassic (Callovian-Tithonian, 165 to 145 million years ago) and known almost exclusively from European deposits (9-12). These enigmatic taxa belong to the extinct family $†$ Pachycormidae (the dagger symbol indicates extinct groups), a stem-teleost clade that is otherwise composed of pelagic predators convergent upon tunas and billfishes (10). Giant tpachycormids include the largest bony fish of all time (the $\sim 9 \mathrm{~m} \uparrow$ Leedsichthys) $(9,13)$, but their short stratigraphic range had implied that they were an inconsequential component of

${ }^{1}$ Department of Earth Sciences, University of Oxford, Parks Road, Oxford OX1 3PR, UK. ${ }^{2}$ Environmental Science Program and Department of Biological Sciences, DePaul University, 2325 North Clifton Avenue, Chicago, IL 60614, USA. ${ }^{3}$ Sternberg Museum of Natural History, Fort Hays State University, 3000 Sternberg Drive, Hays, KS 67601, USA. ${ }^{4}$ Natural History Museum and Biodiversity Research Center, University of Kansas, 1345 Jayhawk Boulevard, Lawrence, KS 66045 USA. ${ }^{5}$ Division of Ecology and Evolutionary Biology, Faculty of Biomedical and Life Sciences, University of Glasgow, University Avenue, Glasgow G12 8QQ, UK. 'Triebold Paleontology and Rocky Mountain Dinosaur Resource Center, 201 South Fairview Street, Woodland Park, CO 80863, USA.

*To whom correspondence should be addressed. E-mail: mattf@earth.ox.ac.uk 
Mesozoic marine ecosystems and a minorand ultimately unsuccessful - experiment in suspension feeding at large body sizes.

Here, we report newly recognized remains of suspension-feeding †pachycormids ranging from the lower Middle Jurassic to the Upper Cretaceous and discuss the implications of our discoveries for Mesozoic marine ecosystems. With the exception of one recently discovered specimen, these fossils were housed in museum collections in which they were either unstudied or had been described but incorrectly identified in the 19th century. Further preparation and examination, combined with an existing systematic framework $(10,12)$, led us to revise previous interpretations of this material.

The fossils reported here include a generically indeterminate cranium from the lower Middle Jurassic (Bajocian, 172 to 168 million years ago) Inferior Oolite of Dorset, UK (Fig. 1); the nearly complete skull of $\dagger$ Rhinconichthys taylori gen. et sp. nov. (14) from the lower Upper Cretaceous (Cenomanian, 100 to 94 million years ago) Lower Chalk of Kent, UK (Fig. 1); a similar fish from the Upper Cretaceous (Cenomanian) Middle Yezo Group of Hokkaido, Japan (15); and multiple specimens of $\dagger$ Bonnerichthys gladius gen. nov. (16) from mid-upper Upper Cretaceous (Coniacian-Maastrichtian, 89 to 66 million years ago) deposits of the Western Interior Seaway and Coastal Plain in the United States (Fig. 2) $(15,17,18)$.

These specimens reveal the anatomy of suspension-feeding †pachycormids, previously known exclusively from poorly understood Jurassic fossils. Material of †Leedsichthys is crushed, fragmented, and disarticulated $(9,11)$, and detailed structure is obscure in rare articulated examples of $\uparrow$ Asthenocormus (10) and $\uparrow$ Martillichthys (12). We base our description on $\uparrow$ Bonnerichthys (Fig. 2).

The snout is covered by a median rostrodermethmoid, which is a †pachycormid synapomorphy $(10,15,19)$. Two lateral projections along the oral margin are unknown in other forms, but their position suggests that they might be coossified premaxillae. Thickened ridges trace the lateral margins of the rostrodermethmoid, mark the position of the supraorbital canal, and imply that the rostrodermethmoid of $\uparrow$ Bonnerichthys also incorporates the nasals. The rectangular frontal bears a ridge on its visceral surface, marking the course of the supraorbital sensory canal. The hookshaped dermosphenotic lies lateral to the frontal, defines the dorsal margin of the orbit, and bears the anastomosis between the infraorbital and otic sensory canals. A triradiate canal-bearing ossification is identified as a dermopterotic. There is no indication of sutural contacts between the dermosphenotic, dermopterotic, and frontal, or between the frontal and the rostrodermethmoid. The condition in $\uparrow$ Bonnerichthys is derived relative to all other †pachycormids, in which dermal bones of the skull roof are tightly linked.

As in many suspension-feeding fishes (4), the dentary of the lower jaw and the maxilla of the upper jaw are elongate and edentulous. Absence of dentition even extends to the prearticular, which lines the inner surface of the mandible, and the parasphenoid, which forms much of the roof of the oral chamber. The parasphenoid is pierced by paired foramina for the internal carotid arteries, a derived feature of teleosts (15).

Members of the operculogular series recovered for $†$ Bonnerichthys include the opercle, subopercle, and gular plate. The hyoid arch is represented by large, imperforate hyomandibulae with well-developed opercular processes and rod-shaped ceratohyals. Gill-arch remains include hypo- and infrapharyngobranchials with complex articular surfaces, plus long and deeply grooved cerato- and epibranchials. Enlarged gill rakers bearing long, needle-like projections are found in $\uparrow$ Asthenocormus, $\dagger$ Leedsichthys, and $\uparrow$ Rhinconichthys $(9,10,12,15)$. These probable suspension-feeding structures have not yet been recovered for $\dagger$ Bonnerichthys.

Typical of tpachycormids, the pectoral fins are scythe-shaped. The leading edge of the fin is fused, with an irregular margin that contrasts with the precisely patterned serrations in some
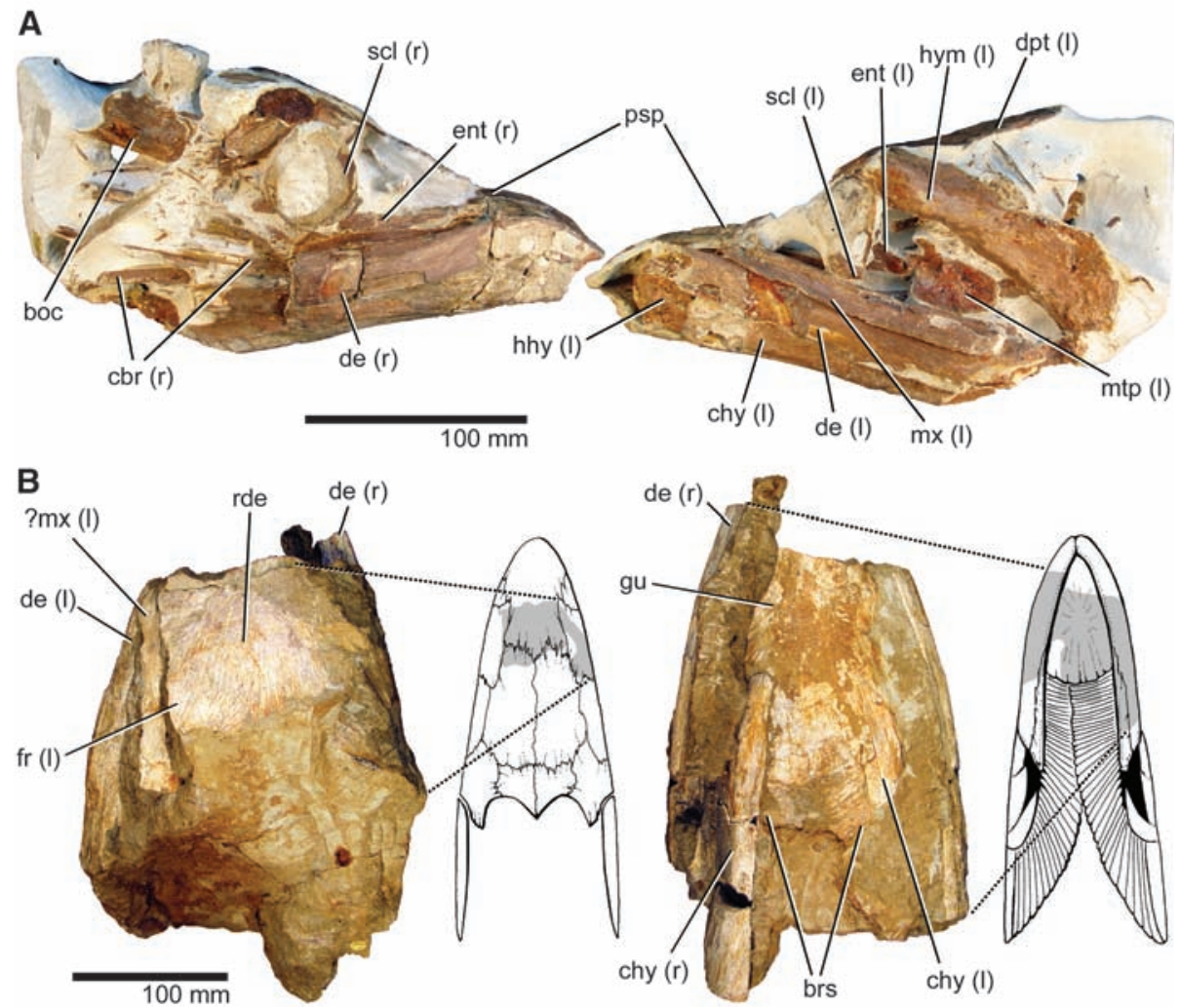

Fig. 1. Newly recognized fossils of giant Mesozoic suspension-feeding bony fishes. (A) †Rhinconichthys taylori gen. et sp. nov., BMNH 219, from the lower Upper Cretaceous (Cenomanian) Lower Chalk of Kent, UK, in right- and left-lateral views. (B) Indeterminate edentulous †pachycormid, BMNH P.41669, from the lower Middle Jurassic (Bajocian) Inferior Oolite of Dorset, UK, in dorsal and ventral view (anterior is toward the top). Matrix has been digitally masked so as to enhance contrast, and preserved bone that would have been visible externally in the ventral and dorsal views is shaded in tentative reconstruction based on †Martillichthys and †Pachycormus. Scale bars apply only to fossils. boc, basioccipital; brs, branchiostegal rays; cbr, certobranchials; chy, anterior ceratohyal; de, dentary; dpt, dermopterotic; ent, entopterygoid; fr, frontal; gu, median gular; hhy, hypohyal; hym, hyomandibula; mtp, metapterygoid; mx, maxilla; psp, parasphenoid; rde, rostrodermethmoid; and scl, sclerotic ring. Paired bones are listed as right ( $r$ ) or left (l). 
Fig. 2. †Bonnerichthys gladius gen. nov., a giant suspension-feeding bony fish from the Upper Cretaceous of the United States. (A) Neurocranium and parasphenoid in ventral view. (B) Gular plate in ventral view. (C) Cranial and pectoral skeleton, shown in right-lateral view. Bones that were reconstructed from other specimens are shown in gray. (D) Hypural plate in right-lateral view. Scale bar in (C) applies to (A) to (D). (A) to (C) show specimen KUVP 60692; (D) shows specimen FHSM (Sternberg Museum, Hays, Kansas) VP-17428. (E) Tentative reconstruction in ventral (top) and lateral (bottom) views, indicating life position of bones shown in (A) to (D). ant, antorbital; ar, articular; cle, cleithrum; dsp, dermosphenotic; ect, ectopterygoid; f.hym, hyomandibular facet of neurocranium; op, opercle; p.f, pectoral fin; qu, quadrate; sco, scapulocoracoid; and sop, subopercle. Other abbreviations are as in Fig. 1.

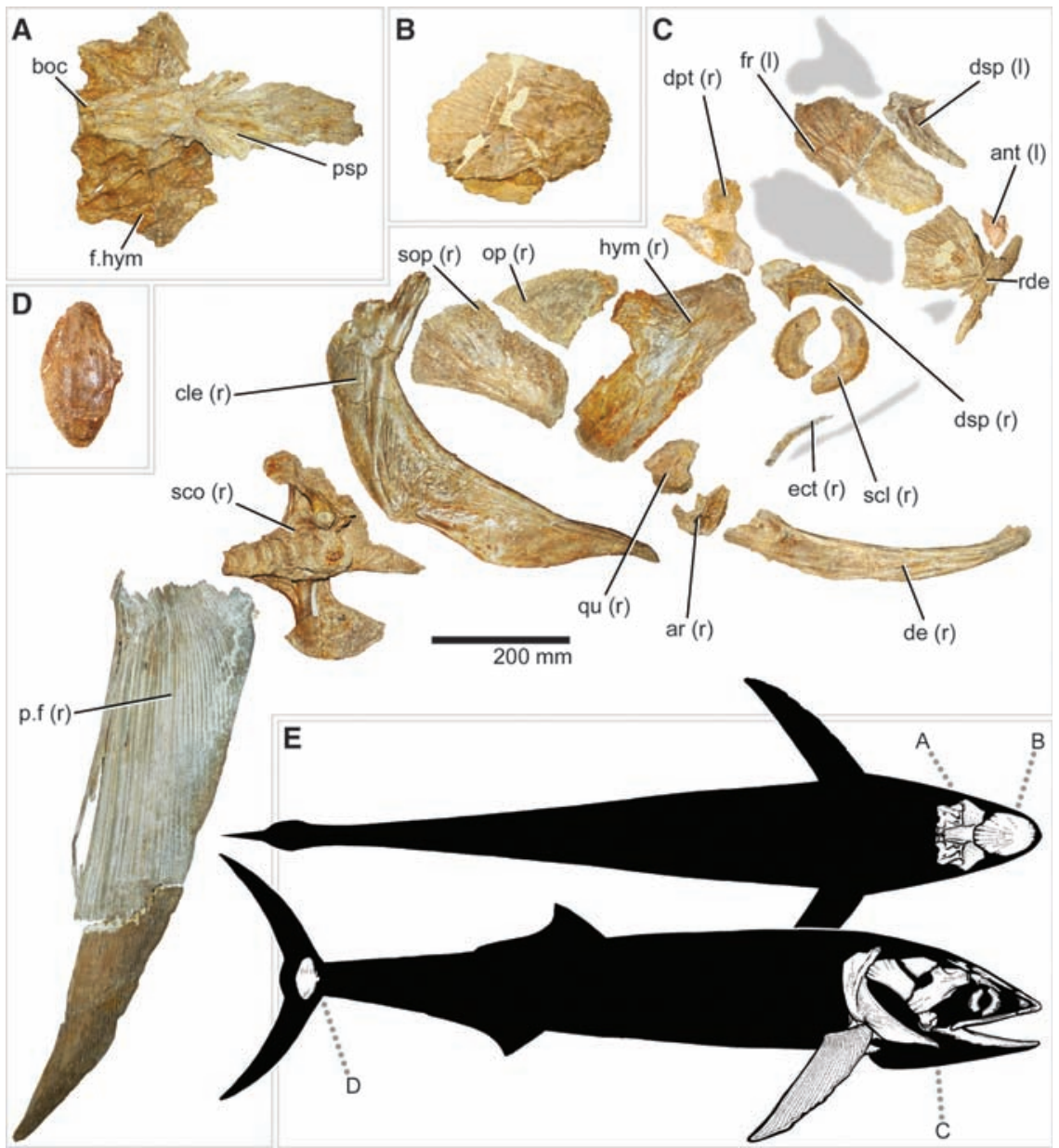

A cladistic analysis provides robust support

Fig. 3. Stratigraphic distribution of giant tpachycormid fishes and modern planktivorous whales and chondrichthyans (icons of living groups are not shown to scale). Previous occurrences of suspension-feeding tpachycormids were confined to a short interval in the Jurassic (shown as a thin line representing †Leedsichthys, $\dagger$ Martillichthys, and $†$ Asthenocormus), but occurrences reported here (shown as thick lines) expand this group's stratigraphic range to approximately 100 million years. Convincing records of modern large-bodied planktivorous vertebrates only appear in the Paleogene, after the extinction of giant tpachycormids.

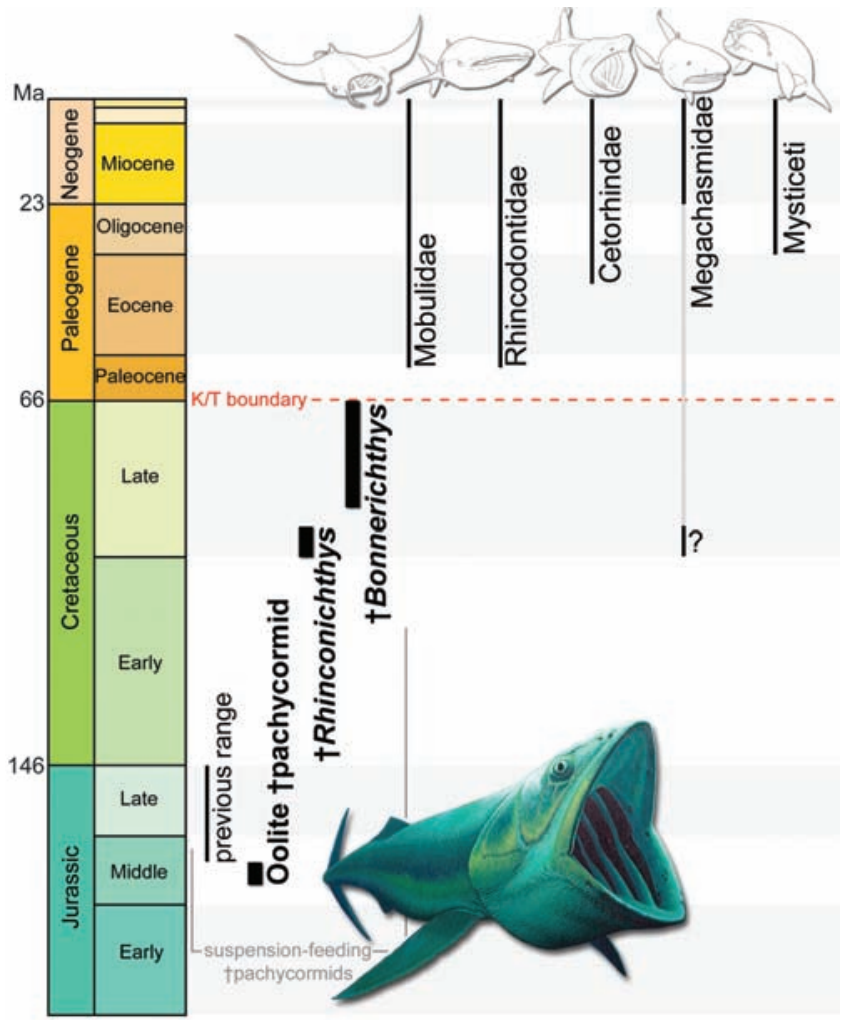
for the monophyly of a clade comprising $\uparrow$ Bonnerichthys plus other large edentulous †pachycormids and reinforces the interpretation of tpachycormids as stem teleosts (15). This subset of †pachycormids is a unique example of suspension feeding at massive body sizes within the teleost total group (23), which is a diverse radiation that otherwise contains a bewildering array of bodyplans and whose living representatives are taxonomic dominants in marine vertebrate faunas (22). With lengths between 5 and $9 \mathrm{~m}$, †Bonnerichthys and $\dagger$ Leedsichthys are comparable in size with some modern suspensionfeeding sharks $(4,22)$. Even the more modestly sized $\uparrow$ Martillichthys and $\uparrow$ Asthenocormus are ecological giants in comparison with extant planktivorous teleosts. At over $2 \mathrm{~m}$, these †pachycormid genera are an order of magnitude longer - and by extension several orders of magnitude more massive - than living teleost suspension feeders, most of which are on the order of $10 \mathrm{~cm}$ long (23). The only moderately large planktivorous actinopterygian (the more extensive bony fish clade that contains teleosts) is the paddlefish Polyodon. This sturgeon relative is confined to the freshwaters of North America and rarely exceeds $2 \mathrm{~m}$ in length despite a greatly elongated rostrum (24). 
The discovery of early Middle Jurassic and Late Cretaceous †pachycormids with anatomical features that are consistent with suspension feeding (4) alters the picture of the evolution of this ecological guild in the Mesozoic and afterward. Oceans during much of this interval have been viewed as devoid of large-bodied suspension feeders (25), but we now recognize that pachycormids occupied this ecological role for much of the Mesozoic (Fig. 3). Marine reptiles diversified prolifically during this geological interval, attaining massive sizes and evolving specializations attributed to suction and ram feeding (26), but there is no clear evidence that they ever adopted planktivory. This observation, coupled with the perceived absence of large-bodied planktivores during most of the Mesozoic, led to suggestions that anatomical constraints prevented these otherwise diverse marine amniote clades from exploiting suspension feeding (25). Our findings suggest that marine reptiles might have been excluded from this trophic strategy by incumbent †pachycormids.

The first fossil occurrences of modern largebodied suspension feeders are confined to the Cenozoic: manta rays and whale sharks in the late Paleocene (1), basking sharks in the midEocene (2), and plankton-feeding whales near the Eocene-Oligocene boundary (3). The only example with a possible Mesozoic record is the megamouth shark Megachasma, but there is a 75million-year interval between a few isolated Late Cretaceous teeth and the next oldest occurrence, which dates to the late Oligocene-early Miocene (27). The radiation of large-bodied suspensionfeeding chondrichthyans and whales in the Paleogene follows the disappearance of $\uparrow$ Bonnerichthys and many other large-bodied marine teleosts $(28,29)$ during the end-Cretaceous extinction, suggesting that familiar modern groups of planktivores diversified into the ecospace vacated by giant †pachycormids.

\section{References and Notes}

1. H. Cappetta, C. Duffin, J. Zidek, in The Fossil Record 2, M. Benton, Ed. (Chapman \& Hall, London, 1993), pp. 593-609.

2. A. L. Cione, M. A. Reguero, Antarct. Sci. 10, 83 (1998).

3. E. M. G. Fitzgerald, Proc. Biol. Sci. 273, 2955 (2006).

4. S. L. Sanderson, R. Wassersug, in The Skull, vol. 3, J. Hanken, B. K. Hall, Eds. (Univ. of Chicago Press, Chicago, IL, 1993), pp. 37-112.

5. S. N. Jarman, Biol. J. Linn. Soc. Lond. 73, 199 (2001).

6. P. G. Falkowski et al., Science 305, 354 (2004).

7. A. Bartholomai, Mem. Queensl. Mus. 49, 521 (2004).

8. L. Cavin, P. L. Forey, in Mesozoic Fishes 4-Homology and Phylogeny, G. Arratia, H.-P. Schultze, M. V. H. Wilson, Eds. (Verlag Dr. Friedrich Pfeil, München, 2008), pp. 199-216.

9. D. M. Martill, N. Jahrb, Geol. Palaeontol. 1988, 670 (1988).

10. P. Lambers, thesis, Rijksuniversiteit Groningen, Groningen, Netherlands (1992).

11. J. Liston, in Mesozoic Fishes 3-Systematics, Paleoenvironments and Biodiversity, G. Arratia, A. Tintori, Eds. (Verlag Dr. Friedrich Pfeil, München, 2004), pp. 379-390.

12. J. Liston, in Mesozoic Fishes 4-Homology and Phylogeny, G. Arratia, H.-P. Schultze, M. V. H. Wilson Eds. (Verlag Dr. Friedrich Pfeil, München, 2008), pp. 181-198.
13. J. J. Liston, L. F.Noè, Arch. Nat. Hist. 31, 236 (2004).

14. Etymology: The generic name is a homophone of an unpublished name by G. Mantell ("Rhynchonichthys") and evokes the whale shark Rhincodon. The specific name honors H. W. Taylor, collector of the type. Systematics: Osteichthyes Huxley, 1880; Actinopterygii Woodward, 1891; Teleostei Müller, 1846 (sensu de Pinna 1996); †Pachycormidae Woodward, 1895; and †Rhinconichthys taylori gen. et sp. nov. Holotype: BMNH (The Natural History Museum, London) 219, nearly complete three-dimensional skull lacking anterior skull roof and posterior portions of lower jaws. Diagnosis of genus and species: Edentulous tpachycormid differing from other members of that group in having exceptionally elongated posterior processes of the dermopterotics and a proximal head of hyomandibula rounded rather than laterally compressed. Locality and age: Lower Chalk (Late (retaceous, Cenomanian), Burham, Kent, UK.

15. Materials and methods are available as supporting material on Science Online.

16. Etymology: The generic name honors the Bonner family, Scott City, Kansas, which has made many important discoveries in the Niobrara Formation, including KUVP (University of Kansas Natural History Museum, Lawrence, Kansas) 60692. Systematics: Osteichthyes Huxley, 1880; Actinopterygii Woodward, 1891; Teleostei Müller, 1846 (sensu de Pinna 1996); †Pachycormidae Woodward, 1895; †Bonnerichthys nov. gen.; and †Bonnerichthys gladius (Cope, 1874), comb. nov. Holotype: AMNH (American Museum of Natural History, New York) FF 1849, incomplete pectoral fin. Diagnosis of genus and species: Edentulous tpachycormid differing from other members of that group in having a rostrodermethmoid with ventrolateral processes, basioccipital with deep aortic groove, dermal bones of skull unsutured, and anterior margins of pectoral fins irregularly crenellated. Locality and age: Type from Niobrara Formation (Late Cretaceous, Coniacian(ampanian), Kansas, USA

17. ]. D. Stewart, in Geology, Paleontology and Biostratigraphy of Western Kansas, M. E. Nelson Ed. (Fort Hays State Univ., Hays, KS, 1988), pp. 80-94.
18. D. C. Parris, B. S. Grandstaff, W. B. Gallagher, Spec. Pap. Geol. Soc. Am. 427, 99 (2007).

19. A. J. Mainwaring, thesis, Westfield College, University of London, London, UK (1978).

20. A. S. Woodward, The Fossil Fishes of the English Chalk (Palaeontographical Society, London, UK, 1902).

21. H. L. Jessen, Fossils Strata 1, 1 (1972).

22. J. S. Nelson, Fishes of the World (Wiley, Hoboken, N], 2006)

23. J. A. Freedman, D. L. G. Noakes, Rev. Fish Biol. Fish. 12, 403 (2002)

24. L. M. Page, B. M. Burr, A Field Guide to Freshwater Fishes of North America and North of Mexico (Houghton Mifflin, Boston, 1991).

25. R. Colin, C. M. Janis, in Ancient Marine Reptiles, J. M. Callaway, E. L. Nicholls, Eds. (Academic Press, San Diego, CA, 1997), pp. 451-466.

26. E. M. Nicholls, M. Manabe, J. Vertebr. Paleontol. 24, 838 (2004).

27. K. Shimada, J. Vertebr. Paleontol. 27, 512 (2007).

28. L. Cavin, in Geological and Biological Effects of Impact Events, E. Buffetaut, C. Koeberl, Eds. (Springer Verlag, Berlin, 2001), pp. 141-158.

29. M. Friedman, Proc. Natl. Acad. Sci. U.S.A. 106, 5218 (2009).

30. M.F. was funded by an Environmental Protection Agency Science to Achieve Results Fellowship (award FP916730). We thank T. Uyeno and M. Manabe for provenance data for the Japanese pachycormid, S. Moore-Fay for exacting specimen preparation, R. Nicholls for his reconstruction of $\dagger$ Bonnerichthys, and $M$. Brazeau, L. Sallan, and three anonymous reviewers for their constructive comments.

\section{Supporting Online Material}

www.sciencemag.org/cgi/content/full/327/5968/990/DC1

SOM Text

Figs. S1 to S15

References

16 November 2009; accepted 25 January 2010

$10.1126 /$ science. 1184743

\title{
Climate, Critters, and Cetaceans: Cenozoic Drivers of the Evolution of Modern Whales
}

\author{
Felix G. Marx ${ }^{1,2 *}$ and Mark D. Uhen ${ }^{3}$
}

Modern cetaceans, a poster child of evolution, play an important role in the ocean ecosystem as apex predators and nutrient distributors, as well as evolutionary "stepping stones" for the deep sea biota. Recent discussions on the impact of climate change and marine exploitation on current cetacean populations may benefit from insights into what factors have influenced cetacean diversity in the past. Previous studies suggested that the rise of diatoms as dominant marine primary producers and global temperature change were key factors in the evolution of modern whales. Based on a comprehensive diversity data set, we show that much of observed cetacean paleodiversity can indeed be explained by diatom diversity in conjunction with variations in climate as indicated by oxygen stable isotope records $\left(\delta^{18} 0\right)$.

$\mathrm{M}$ odern cetaceans (Neoceti), the mysticetes and odontocetes, show a number of mass-feeding adaptations beyond the immediate demands of an aquatic existence (1). Whereas mysticetes have become edentulous and rely on baleen to filter food from the water, odontocetes have evolved the ability to search for prey by means of echolocation. What unites these two different adaptive strategies is their effectiveness in terms of mass feeding:
Whereas mysticetes obtain enormous amounts of small prey by filtering vast quantities of water, odontocetes may be able to use their biosonar to locate the vertically migrating layers of plankton with their associated grazers and predators known as deep scattering layers (1). To support such large and abundant apex predators, the ecosystems exploited by cetaceans must be extremely productive, and the energy captured by primary producers must be transmitted very efficiently 